\title{
Sol-gel derived lithium-releasing glass for cartilage regeneration
}

Siwei Li ${ }^{1}$, Anthony L. B. Maçon ${ }^{1}$, Manon Jacqueminn ${ }^{1}$, Molly M. Stevens ${ }^{1,2}$ and Julian R. Jones $^{1}$

1 Department of Materials, Imperial College London, SW7 2AZ, London, UK

2 Department of Bioengineering Imperial College London, SW7 2AZ, London, UK

Corresponding author:

Julian R Jones, Department of Materials, Imperial College London, SW7 2AZ, London, UK

Email: julian.r.jones@imperial.ac.uk 


\section{Abstract}

Wnt-signalling cascade is one of the crucial pathways involved in the development and homeostasis of cartilage. Influencing this pathway can potentially contribute to improved cartilage repair or regeneration. One key molecular regulator of the Wnt pathway is the glycogen synthase kinase-3 (GSK-3) enzyme, the inhibition of which allows initiation of the signalling pathway. This study aims to utilise a binary $\mathrm{SiO}_{2}-\mathrm{Li}_{2} \mathrm{O}$ sol-gel derived glass for controlled delivery of lithium, a known GSK-3 antagonist. The effect of the dissolution products of the glass on chondrogenic differentiation in an in vitro 3-D pellet culture model is reported. Dissolution products that contained $5 \mathrm{mM}$ lithium and $3.5 \mathrm{mM}$ silicon, were capable of inducing chondrogenic differentiation and hyaline cartilaginous matrix formation without the presence of growth factors such as TGF- $\beta 3$. The results suggest that sol-gel derived glass has the potential to be used as a delivery vehicle for therapeutic lithium ions in cartilage regeneration applications.

\section{Key words:}

Cartilage, osteoarthritis, chondrocytes, tissue engineering, sol-gel, bioactive glass, lithium 


\section{Introduction}

Articular cartilage is a highly specialised tissue that reduces joint friction at the extremities of long bones, and acts as a shock absorber. Once damaged, it has limited self-repair capacity due, in part, to its avascular nature. Osteoarthritis (OA), the most common form of arthritis in the aging population, is often the result of untreated cartilage defects. As yet, no current surgical or material-based interventions can reliably lead to repairing the biological composition and biomechanical properties of the native hyaline cartilage. This has prompted the rapid development of tissue engineering approaches, which combine the use of cells, biomaterials and chondrogenic environmental factors ${ }^{1}$. Microfracture procedures utilise bone marrow to produce fibrocartilage in articular lesions, but while successful clinical results have been reported in short term (two years), deterioration tends to occur beyond two years as the fibrocartilage breaks down ${ }^{2}$. Therapeutic agents that can supplement microfracture and promote hyaline cartilage repair would be of great benefit.

The Wnt-signalling cascade, which regulates chondrocyte proliferation, differentiation and maintenance of phenotype, is one of the essential pathways involved in chondrogenesis ${ }^{3-5}$. Glycogen synthase kinase-3 (GSK-3) is a key molecular regulator of the canonical Wnt-signalling ${ }^{6,7}$. The presence of certain agents such as lithium (Li) has been shown to induce the phosphorylation of GSK-3 that in turn resulted in the accumulation of $\beta$-catenin and subsequent formation of a complex with transcription factors to activate the transcription of target genes ${ }^{7,8}$. There is increasing evidence 
that activation of Wnt-signalling by means of GSK-3 antagonist lithium (e.g. in the form of lithium chloride) in cell lines and mesenchymal stem cells has the ability to stimulate the expression of chondrogenic markers ${ }^{9-11}$. Further, lithium has been shown capable of reducing catabolic events in the pathogenesis of $O A^{12-14}$. The controlled administration of lithium at therapeutic level therefore represents an exciting new strategy for cartilage regeneration and/or possible treatment method for patients with joint diseases.

One potential candidate for sustained delivery of lithium into a cartilage defect is bioactive glass. Their dissolution behaviour can be finely tuned by varying their composition, porosity or particle size ${ }^{15-17}$. Cations can be delivered without the need for corresponding anions, such as the chloride in lithium chloride. Several reports have described the incorporation of lithium into melt and sol-gel derived glasses ${ }^{18-22}$. For instance, Wu et al. synthesized ordered mesoporous sol-gel glass scaffolds containing $5 \mathrm{~mol} \%$ of $\mathrm{Li}_{2} \mathrm{O}(\mathrm{Li}-\mathrm{MBG})$, which enhanced the regeneration of osteochondral defects in a rabbit model compared to the glass that did not contain lithium ${ }^{21}$. This, and other glasses containing lithium, were tertiary and quaternary compositions, generally including calcium, phosphate and/or sodium ${ }^{23}$. As a result, this leads to the release of multiple ion species, potentially causing combinational effects on cell metabolism ${ }^{24-27}$. Thus, it is unknown if the biological response induced by these glasses containing lithium ions was due solely to the release of lithium or if lithium acts in combination with other ions already present in the physiological fluid or released from the materials. 
Further, elevated calcium concentrations can induce chondrocyte hypertrophy, an undesirable phenomenon in hyaline cartilage repair ${ }^{28}$.

We developed binary sol-gel $\mathrm{SiO}_{2}-\mathrm{Li}_{2} \mathrm{O}$ glass containing $10 \mathrm{~mol} \%$ of $\mathrm{Li}_{2} \mathrm{O}$, releasing 5 $\mathrm{mM}$ of lithium in culture media when incubated at $75 \mathrm{mg} / 50 \mathrm{ml}$, as a model glass for sustained delivery of lithium without other cations ${ }^{15}$. The previous study showed the glasses to be not cytotoxic at the concentrations studied. Here, the response of chondrocytes to the dissolution products of the $\mathrm{SiO}_{2}-\mathrm{Li}_{2} \mathrm{O}$ glass was demonstrated for the first time, in a 3-D pellet culture model.

\section{Materials and Methods}

Chemicals and cell culture reagents were purchased from Sigma-Aldrich and Life Technologies UK unless specified otherwise.

\section{Synthesis of $\mathrm{S} 100$ and $\mathrm{SiO}_{2}-\mathrm{Li}_{2} \mathrm{O}$ sol-gel derived glass}

Binary sol-gel glass $90 \mathrm{~mol} \% \mathrm{SiO}_{2}-10 \mathrm{~mol} \% \mathrm{Li}_{2} \mathrm{O}\left(\mathrm{SiO}_{2}-\mathrm{Li}_{2} \mathrm{O}\right)$ was synthesized as previously described by Maçon et al. ${ }^{15}$. Tetraethylorthosilicate (TEOS) was first hydrolysed for $1 \mathrm{~h}$ in presence of deionised water (DiW) and nitric acid (2 M) by vigorous agitation in a PTFE mould. The molar ratio of TEOS to DiW was fixed to 1:12, whereas nitric acid (2 M) was added by volume amounting to $1 / 6$ of the volume of DiW. The lithium citrate tribasic tetrahydrate was then slowly added to the sol with moderate agitation, targeting a molar ratio of oxide equal to $\mathrm{SiO}_{2}: \mathrm{Li}_{2} \mathrm{O}=90: 10$. Glass without lithium $\left(100 \% \mathrm{SiO}_{2}\right)$ was also synthesized as a control and referred to as $\mathrm{S} 100$. After 1 
$\mathrm{h}$, the moulds were tightly sealed and left for 3 days at room temperature for the sol to gel and subsequently aged at $60{ }^{\circ} \mathrm{C}$ for 3 days. The glasses were then dried (unsealed) at $130^{\circ} \mathrm{C}$ using a 3-stage programme $\left(60^{\circ} \mathrm{C}\right.$ for $20 \mathrm{~h}, 90^{\circ} \mathrm{C}$ for $24 \mathrm{~h}$ and $130^{\circ} \mathrm{C}$ for $40 \mathrm{~h}$, ramp $\left.=1{ }^{\circ} \mathrm{C} / \mathrm{min}\right)$ and stabilised at $500{ }^{\circ} \mathrm{C}$ using a 2 stage programme $\left(300^{\circ} \mathrm{C}\right.$ for 2 hours, $500{ }^{\circ} \mathrm{C}$ for $5 \mathrm{~h}$, ramp $=1{ }^{\circ} \mathrm{C} / \mathrm{min}$ ). The stabilised glasses, which were amorphous ${ }^{15}$, were then ground and sieved (average diameter $=54.5 \pm 20.1 \mu \mathrm{m}$ ).

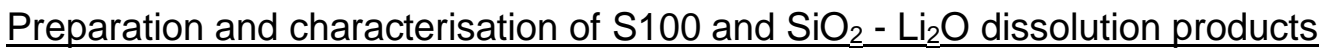

Dissolution products released from $\mathrm{S} 100$ and $\mathrm{SiO}_{2}-\mathrm{Li}_{2} \mathrm{O}$ glass powders $(75 \mathrm{mg}$ in 50 $\mathrm{ml}$ DMEM) were prepared at $37^{\circ}$ over $4 \mathrm{~h}$. All dissolution products were filter sterilised prior to use in cell culture. The concentrations of Li and Si elements in the media were determined using a Thermo Scientific iCaP 6300 Duo inductive coupled plasma optical emission spectrometer. The samples were prepared by diluting the collected aliquots with distilled water by a factor of 10 and filtered using $0.45 \mu \mathrm{m}$ cellulose filters. Mixed standards of Si and $\mathrm{Li}(1000 \mu \mathrm{g} / \mathrm{ml}$ stock concentration) were prepared at 0, 2, 5, 20 and $40 \mu \mathrm{g} / \mathrm{ml}$ for calibration. Si and Li were measured in the axial direction of the plasma flame.

\section{$\underline{\text { Cell culture }}$}

The murine chondrogenic cell line ATDC5 was culture expanded in monolayer in basal DMEM supplemented with $100 \mathrm{unit} / \mathrm{ml}$ penicillin, $100 \mu \mathrm{g} / \mathrm{ml}$ streptomycin, 5\% (v/v) FCS (foetal calf serum) and $1 \times$ ITS liquid supplement $(10 \mu \mathrm{g} / \mathrm{ml}$ insulin, $5.5 \mu \mathrm{g} / \mathrm{ml}$ transferrin 
and $5 \mathrm{ng} / \mathrm{ml}$ selenite premix). Cultures were maintained in humidified atmosphere at $37^{\circ} \mathrm{C}, 5 \% \mathrm{CO}_{2}$ and $21 \% \mathrm{O}_{2}$. Upon confluence cells were passaged using $500 \mathrm{\mu g} / \mathrm{ml}$ trypsin-EDTA (ethylene diamine tetra-acetic acid).

\section{$\underline{\text { Pellet culture }}$}

Pellet cultures that provide three dimensional environments for chondrocytes were performed in accordance with the protocol published previously ${ }^{29,}{ }^{30}$. Briefly, ATDC5 cells were harvested and resuspended at $2.5 \times 10^{5}$ cells $/ \mathrm{ml}$. To form pellets, $1 \mathrm{ml}$ of cell suspension was added to each sterile $25 \mathrm{ml}$ polycarbonate universal tube and centrifuged at $400 \times \mathrm{g}$ for 5 minutes at $4^{\circ} \mathrm{C}$. The resulting cell pellets were not dispersed and were cultured in humidified atmosphere at $37^{\circ} \mathrm{C}, 5 \% \mathrm{CO}_{2}$ and $21 \% \mathrm{O}_{2}$ for up to 21 days with media change every 2 days. Cell pellets were cultured in the following media, with and without chondrogenic supplements: 1) basal DMEM, 2) basal DMEM + $\mathrm{SiO}_{2}$ $\mathrm{Li}_{2} \mathrm{O}$ and 3) basal DMEM $+\mathrm{S} 100$. The chondrogenic supplements consisted of 10 ng/ml rhTGF- $\beta 3$ (PeproTech, UK), $100 \mu \mathrm{M}$ ascorbate-2-phosphate and $10 \mathrm{nM}$ dexamethasone ${ }^{31,32}$. Day 7, 14 and 21 pellets were collected for various analytical procedures.

\section{$\underline{\text { Histological and immunohistochemical staining }}$}

Pellets were fixed in $4 \%(\mathrm{w} / \mathrm{v})$ paraformaldehyde (PFA) overnight and processed through graded ethanol (50 - 100\%) and histoclear prior to embedding in paraffin wax. Sequential sections were cut at $7 \mu \mathrm{m}$ thick and mounted on glass slides for histological 
and immunohistochemical staining. Images were captured using an Olympus BX51 system microscope (Olympus Microscopy, UK).

a Alcian blue \& Sirius red: Following nuclear staining with Weigert's haematoxylin, sections were stained with Alcian blue $8 \mathrm{GX}(5 \mathrm{mg} / \mathrm{ml}$ in $1 \%(\mathrm{v} / \mathrm{v})$ glacial acetic acid) and Sirius red F3B (10 mg/ml in saturated picric acid) ${ }^{33}$.

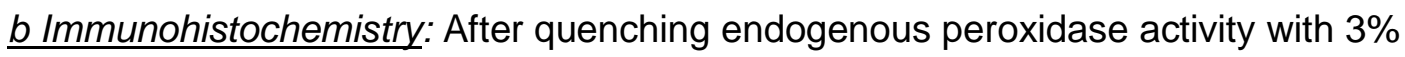
(v/v) $\mathrm{H}_{2} \mathrm{O}_{2}$ and blocking with $10 \mathrm{mg} / \mathrm{ml} \mathrm{BSA}$ in PBS, sections were incubated with relevant primary antiserum overnight at $4^{\circ} \mathrm{C}$. This was followed by $1 \mathrm{~h}$ incubation each with the appropriate biotinylated secondary antibody and ExtrAvidin ${ }^{\circledR}$-Peroxidase. Visualisation of the immune complex involved the avidin-biotin method linked to peroxidase and AEC (3-amino-9-ethylcarbazole), resulting in a reddish brown reaction product. Negative controls (omission of the primary antisera) were included in all immunohistochemistry procedures. No staining was observed in all negative control sections.

The anti-SOX9 antibody (rabbit polyclonal, IgG, Sigma-Aldrich, UK) was used at a dilution of $1: 150$ in $10 \mathrm{mg} / \mathrm{ml}$ BSA in PBS following the heat antigen retrieval procedure, which involved treating sections in $0.01 \mathrm{M}$ citrate buffer $\left(\mathrm{pH} \mathrm{6.0)}\right.$ at $80^{\circ} \mathrm{C}$ for 20 minutes prior to the application of the standard immunohistochemistry procedure.

For Collagen Type I, II and X immunostaining, sections were treated with Type-I hyaluronidase at $37^{\circ} \mathrm{C}$ for 20 minutes. The anti-Collagen Type I, anti-Collagen Type II 
and anti-Collagen Type $\mathrm{X}$ antibodies (rabbit polyclonal, IgG, Abcam, UK) were used at a dilution of $1: 1000,1: 500$, and $1: 100$ respectively.

\section{Gene expression analysis}

Pellets were lysed and total RNA was extracted using Qiagen RNeasy kit (Qiagen, UK) following manufacturer's instructions. The RNA samples were treated with DNase-1 reagent and reverse-transcribed using the SuperScript ${ }^{\circledR}$ VILO ${ }^{\mathrm{TM}}$ kit (Invitrogen, UK). qPCR assays were carried out using the QuantStudio ${ }^{\text {TM }} 6$ Flex Real-Time PCR system (Applied Biosystems, Thermo Fisher Scientific, UK) for analysing the expression of the genes, primer sequences for which are listed below. The relative expression of genes of interest $\left(\Delta \mathrm{C}_{\mathrm{T}}\right)$ was normalised to the housekeeping gene/endogenous control, $\beta$ actin. Statistical analysis was performed at the level of $\Delta \mathrm{C}_{\mathrm{T}}$.

The following primer sequences were used in the current study. $\beta$-actin: $F$ 5'CACCCTGTGCTGCTCACCGAGGCC-3', R 5'- CCACACAGATGACTTGCGCTCAGG3'. col1a1: F 5'-GAACGGTCCACGATTGCATG-3', R 5'-

GGCATGTTGCTAGGCACGAAG-3'. col2a1: F 5'-

CACACTGGTAAGTGGGGCAAGACCG-3', R 5'-

GGATTGTGTTGTTTCAGGGTTCGGG-3'. col10a1: F 5'-

AAAGCTTACCCAGCAGTAGG-3', R: 5'- ACGTACTCAGAGGAGTAGAG-3' 34, 35.

Dimethylmethylene blue (DMMB) GAG assay 
The quantity of sulphated GAGs synthesized by the cells at each time point was determined by the DMMB assay ${ }^{36,37}$. In brief, pellets were digested overnight at $60^{\circ} \mathrm{C}$ with papain (working solution containing $0.7 \mathrm{U}$ papain prepared in papain buffer containing $0.1 \mathrm{M}$ sodium acetate, $0.01 \mathrm{M}$ disodium EDTA and $0.005 \mathrm{M}$ cysteine hydrochloride in $0.2 \mathrm{M}$ potassium phosphate buffer, $\mathrm{pH}$ 6.4). The digested samples were briefly centrifuged to sediment undigested debris from the extracts. $20 \mu \mathrm{l}$ of the diluted extract (1 in 10 dilution in papain buffer) was then mixed with $200 \mu \mathrm{LMMB}$ reagent (46 $\mu \mathrm{M}$ DMMB, $30 \mathrm{mM}$ sodium formate, $0.5 \%(\mathrm{v} / \mathrm{v})$ ethanol and $0.2 \%(\mathrm{v} / \mathrm{v})$ formic acid) and the optical density of the resultant solution was measured at $540 \mathrm{~nm}$. Each extract was assayed in triplicate in a 96-well plate. The GAG content of samples was extrapolated from a standard curve derived from the optical density values of standard solutions of chondroitin sulphate from shark cartilage (concentration range: 0 $100 \mu \mathrm{g} / \mathrm{ml})$.

\section{Statistical analysis}

Statistical analysis was performed using Mann-Whitney U test with Bonferroni correction. Results were deemed significant if the probability of occurrence by random chance was less than $5 \%$ (i.e. $p<0.05$ ). 


\section{Results}

Histological and immunohistochemical analysis of chondrogenic differentiation of ATDC5 cells

At each time point, pellets of ATDC5 cells were assessed for chondrogenic differentiation and cartilaginous matrix formation by a range of histological and immunohistochemical techniques (Figure 1 and Figure 2). Suboptimal chondrogenic differentiation was observed in pellets cultured in basal DMEM alone. The $\mathrm{SiO}_{2}-\mathrm{Li}_{2} \mathrm{O}$ glass dissolution products (DMEM containing $5.02 \mathrm{mM} \mathrm{Li}$ and $3.6 \mathrm{mM} \mathrm{Si}$ ) notably improved rate of chondrogenic differentiation. The cartilaginous matrix formation was evident in pellets collected as early as day 7 (Figure 1). The histology of regions that consisted of cartilaginous matrix was reminiscent of native hyaline cartilage tissue ${ }^{38}$. Chondrocytes in distinct lacunae were seen in dense proteoglycan matrix stained with Alcian blue (Figure 1). Red-stained collagen was also present. The regions that consisted of cartilaginous matrix was also notably larger in early stage pellets cultured in the $\mathrm{SiO}_{2}-\mathrm{Li}_{2} \mathrm{O}$ glass dissolution products without chondrogenic supplements in comparison to basal control.

When chondrogenic supplements were not given, Sox9, an early marker for chondrocyte differentiation and function, was immunolocalised to more chondrocytes of the day-7 pellets cultured in $\mathrm{SiO}_{2}-\mathrm{Li}_{2} \mathrm{O}$ glass dissolution products in comparison to basal DMEM and S100 dissolution products (Figure 2). 
Day-21 pellets cultured in $\mathrm{SiO}_{2}-\mathrm{Li}_{2} \mathrm{O}$ glass dissolution products also demonstrated more prominent staining of Collagen Type II, a marker of hyaline cartilaginous matrix, than those cultured in basal DMEM. The dissolution products of S100, silicate sol-gel glass, which did not contain lithium (DMEM containing 3.6 mM Si only), did not appear to have stimulatory effects on chondrogenic differentiation and hyaline cartilaginous matrix formation of ATDC5 cells.

Exposure to the dissolution products from either type of glass appeared to increase expression of Collagen Type X, a marker for chondrocyte hypertrophy, compared to basal media. The addition of chondrogenic supplements, including TGF- $\beta 3$, appeared to supress chondrocyte hypertrophy. All test conditions did not appear to affect the expression of Collagen Type I, marker for fibrous cartilage. Pellets cultured in all chondrogenic conditions also demonstrated superior cartilaginous matrix formation, in particular during early stages. The combination of chondrogenic supplements and $\mathrm{SiO}_{2}$ - $\mathrm{Li}_{2} \mathrm{O}$ glass dissolution products also appeared to have synergetic effects.

\section{Gene expression analysis and GAG quantification}

Analysis of chondrogenic gene expression was performed using real-time qPCR. The expression levels of genes of interest were normalised to the expression level of housekeeping gene $\beta$-actin (Figure 3 ). The results of gene expression analysis confirmed the observations from histological and immunohistochemical staining. $\mathrm{SiO}_{2}$ $\mathrm{Li}_{2} \mathrm{O}$ glass dissolution products were capable of up-regulating transcription factor Sox 9 by day 7 without the presence of chondrogenic supplements and this up-regulation was 
not seen with S100. When chondrogenic supplements were used, all SOX9 expression was similar by day 7 and enhanced compared to control and basal media $+\mathrm{SiO}_{2}-\mathrm{Li}_{2} \mathrm{O}$. The expression levels of hyaline cartilage specific gene Col2a1 in day-21 pellets cultured in chondrogenic conditions was significantly up-regulated in comparison to pellets cultured in basal DMEM. The addition of $\mathrm{SiO}_{2}-\mathrm{Li}_{2} \mathrm{O}$ glass dissolution products but without chondrogenic supplements also up-regulated the expression of Col2a1 in pellets to a level similar to those cultured in chondrogenic media (no change compared to control for $\mathrm{S} 100$ without supplements). On the other hand, the expression of Col10a1, a marker for chondrocyte hypertrophy, was up-regulated by both $\mathrm{SiO}_{2}-\mathrm{Li}_{2} \mathrm{O}$ and S100 glass dissolution products by day 21. The expression of Col10a1 was supressed by the presence of chondrogenic supplements, confirming the observations in immunohistochemical analysis. No significant changes in the expression of Col1a1, a marker for fibrous cartilage, were observed in pellets cultured in all test conditions.

The amount of sulphated GAG, the key non-collagenous component of articular cartilage, synthesized in a pellet was determined using quantitative DMMB assay. Pellets cultured in media containing chondrogenic supplements synthesized significantly more sulphated GAG in comparison to those cultured in basal conditions by day 7 (Figure 4). There was little difference between the control and media containing dissolution products when chondrogenic supplements were not present. By day 14, the addition of $\mathrm{SiO}_{2}-\mathrm{Li}_{2} \mathrm{O}$ glass dissolution products alone (without chondrogenic supplements) significantly improved the synthesis of GAG in pellets, compared to control and S100, to a level comparable to those cultured in chondrogenic 
supplements. $\$ 100$ glass dissolution products did not have notable effects on chondrogenic gene expression or GAG synthesis.

\section{Discussion}

The present study demonstrated the potential application of lithium-silica sol-gel derived glass $\left(\mathrm{SiO}_{2}-\mathrm{Li}_{2} \mathrm{O}\right)$ in cartilage regeneration strategies. Conventional tissue engineering treatment methods including autologous chondrocyte implantation ( $\mathrm{ACl})$ require 2 separate surgeries and in vitro cell culture, which are often time/cost consuming and complications such as donor site morbidity and infection persist. Controlled delivery of therapeutic ions therefore represents an exciting prospect for "in situ" articular cartilage repair strategies and sol-gel glasses could be used as a delivery vehicle as their dissolution can be tailored as a function of their composition ${ }^{15}$. $\mathrm{SiO}_{2}$ $\mathrm{Li}_{2} \mathrm{O}$ glass used in the present study was designed to deliver $5 \mathrm{mM}$ of $\mathrm{Li}$. The reason this dose was chosen was that previous studies demonstrated that the effects of lithium on cellular behaviour is dose dependent with optimal cell viability when culture medium contained $5 \mathrm{mM}$ lithium and higher concentration of $\mathrm{Li}(7 \mathrm{mM})$ reduced cell viability ${ }^{9,10}$. One of the benefits of using bioactive glass is that lithium can be delivered effectively in its active ionic form in lieu of conventional chemicals such as lithium chloride, and the delivery can be sustained as the glass dissolves [15].

Wnt family proteins are essential for various developmental and physiological processes. Deregulation of Wnt signalling is associated with a number of diseases including cancer, osteoporosis and degenerative disorders such as Osteoarthritis ${ }^{39,40}$. 
Wnt signals are transmitted through different pathways by selective activation of specific receptors or co-factors and, the canonical cascade through $\beta$-catenin is the most extensively studied pathway ${ }^{41,42}$. In the absence of Wnt, a destruction complex consisting of Adenomatosis polyposis coli (APC), Casein kinase 1 (CK1) and Axin regulates the phosphorylation of $\beta$-catenin through GSK-3 $\beta^{43}$. Lithium ions, often administered in the form of lithium chloride ( $\mathrm{LiCl})$, have been used as a mood stabiliser. It is well established that the therapeutic usefulness of these lithium salts was directly associated with the inhibition GSK-3 ${ }^{44}$.

Since Wnt signalling are actively involved in both pre-natal and adulthood skeletal development ${ }^{45}$, increasing number of studies have investigated the potential of $\mathrm{Li}$ as well as other GSK-3 inhibitors for musculoskeletal tissue engineering applications. The findings regarding the effects of GSK-3 inhibitors on chondrogenic differentiation, however, remain inconclusive.

These conflicting findings were due in part to the cell types and culture conditions used in different studies. Kapadia et al. investigated the role of GSK-3 inhibition (by $15 \mathrm{mM}$ $\mathrm{LiCl}$ ) in endochondral bone development by using an in vitro murine metatarsal bone explant culture model ${ }^{46}$. Chondrocyte differentiation was significantly suppressed with limited expression of Aggrecan and Collagen Type II. Kawata et al. utilised an alternative GSK-3 inhibitor, SB $216763(2.5-20 \mu \mathrm{m})$, for the activation of the Wnt/ßcatenin pathway in monolayer cultured human chondrocytic cell line HCS-2/8 and mRNA levels of aggrecan and col2a 1 were also reported significantly reduced ${ }^{47}$. It is, 
however, arguable that the addition of GSK-3 inhibitor alone resulted in the downregulation of these cartilage-specific markers. Chondrocytes, upon release from 3-D environments, are known to lose their phenotype and capacity to form cartilaginous tissue with a switch to fibroblastic gene expression profile during a known phenomenon, namely dedifferentiation ${ }^{48}$. The 3-D pellet culture model used in the works presented here is more suitable for in vitro investigation of chondrogenic differentiation and cartilaginous matrix formation.

In other studies, the stimulatory effects of GSK-3 antagonist on chondrogenic differntiation of human bone marrow derived stromal cells in 3-D micromass/pellet culture have been reported ${ }^{9,10}$. These studies, however, suggested that the interaction between pathways initiated by both TGF- $\beta 3$ and Li was a prerequisite for the enhanced chondrogenesis. In another study, not only enhanced chondrogenesis but also inhibited adipogenic differentiation were demonstrated using bovine retinal pericyte micromass cultures treated with chondrogenic medium supplemented with both TGF$\beta 3$ and $\mathrm{Li}^{6}$. The results of the work presented here suggest that pathways activated by $\mathrm{Li}$ (and potentially soluble silica) from the $\mathrm{SiO}_{2}-\mathrm{Li}_{2} \mathrm{O}$ glass was capable of enhancing chondrogenesis without the presence of chondroinductive TGF- $\beta 3$. In particular, in comparison to basal conditions, the rate of chondrogenic differentiation was significantly improved in the presence of $\mathrm{SiO}_{2}-\mathrm{Li}_{2} \mathrm{O}$ glass dissolution products and, the formation of cartilaginous matrix can be seen as early as day 7 . 
S100 glass dissolution products (soluble silica only), on the other hand, did not significantly affect chondrogenic differentiation of ATDC5 cells. It was therefore likely that the interaction or cross-talk between the pathways activated by Li and soluble silica that ultimately resulted in the improved chondrogenesis observed in the present study. The importance of Si in musculoskeletal tissue health has been reported in various studies published since as early as the 1970's ${ }^{49-53}$. The number of studies designed to elucidate the biological role of $\mathrm{Si}$ in chondrogenesis, however, are limited. This was likely due to the potential drawbacks associated with the use of Si, i.e. the tendency of Si to stimulate endochondro ossification during bone development and to up-regulate the expression of osteogenic markers such as osteopontin, osteocalcin and Collagen Type ${ }^{51,54,55}$. A similar observation was made in the present study, as pellets cultured in both $\mathrm{SiO}_{2}-\mathrm{Li}_{2} \mathrm{O}$ and $\mathrm{S} 100$ glass dissolution products demonstrated up-regulated expression of Collagen Type X, a marker for chondrocyte hypertrophy, the preceding event of endochondral bone development.

It has to be emphasised, however, that only one concentration of Si was investigated in the work presented here. Therefore, further studies are required to elucidate whether the effects of soluble silica on chondrogenesis are dose dependent and the chondrocyte hypertrophy can be potentially mitigated by developing $\mathrm{SiO}_{2}-\mathrm{Li}_{2} \mathrm{O}$ glass compositions containing alternative Si contents.

TGF- $\beta$ growth factor plays an important role in all stages of chondrogenesis, mesenchymal condensation, cell proliferation, extracellular matrix deposition and 
terminal differentiation. It is well documented that TGF- $\beta$ inhibits chondrocyte terminal differentiation and the expression of Collagen Type $X^{56-58}$. Likewise, chondrocyte hypertrophy and terminal differentiation in pellets cultured in glass dissolution products was repressed by the presence of TGF- $\beta$ in the present study. The present study utilised ATDC5 cell line as an in vitro model to study the influence of $\mathrm{SiO}_{2}-\mathrm{Li}_{2} \mathrm{O}$ glass dissolution products on cellular behaviour during chondrogenesis. The ATDC5 cell line has been shown to go through a sequential process analogy to native skeletal development from early chondrogenic differentiation to terminal chondrocyte mineralisation ${ }^{59}$. In comparison to primary articular chondrocytes and skeletal stem cells (more commonly referred to as mesenchymal stem cells) as well as other chondrocytic cell lines, ATDC5 cells exhibit chondrogenic differentiation at a much higher frequency 59,60 . This could be one of the reasons that some chondrogenic differentiation was evident even in pellets cultured in basal medium and, minimal synergetic effects between TGF- $\beta$ and glass dissolution products were observed in the present study. The responses of more clinically relevant cell populations, namely human articular chondrocytes and adult skeletal stem cells, to GSK-3 inhibitor lithium and $\mathrm{SiO}_{2}-\mathrm{Li}_{2} \mathrm{O}$ glass therefore will be the focus of future investigations.

Here, the dissolution products of $\mathrm{SiO}_{2}-\mathrm{Li}_{2} \mathrm{O}$ sol-gel derived glass were used for the investigation of their effects on chondrogenic differentiation and cartilaginous matrix formation. Since the design goal of this unique binary sol-gel glass was to allow sustained and controlled release of therapeutic ions in situ, it is important to conduct further studies where the use of $\mathrm{SiO}_{2}-\mathrm{Li}_{2} \mathrm{O}$ glass will be in direct contact with articular 
chondrocytes and/or cartilage tissue. This will also allow the investigation of potential interaction with surrounding tissues and the removal mechanism of degradation byproducts.

\section{Conclusion}

We have demonstrated here that biomaterials can be designed and used as an investigational tool towards the understanding of complex biological systems. Silicate ions alone have minimal effects on ATDC5 cell metabolism whereas dissolution products of $\mathrm{SiO}_{2}-\mathrm{Li}_{2} \mathrm{O}$ bioactive glass enhanced ATDC5 cell activities to an extent similar to chondrogenic conditions. The dissolution products of $\mathrm{SiO}_{2}-\mathrm{Li}_{2} \mathrm{O}$ glass, containing Wnt agonist $\mathrm{Li}$, were able to enhance the rate of chondrogenic differentiation as well as GAG deposition, which are crucial for in situ cartilaginous matrix formation. The data presented here suggest that sol-gel derived glasses have the potential to be used as effective delivery vehicles for lithium, in its active ionic form, in cartilage regeneration applications.

\section{Acknowledgements}

The authors would like to thank EPSRC (EP/I020861/1 and EP/M019950/1) for funding.

\section{Declaration of conflicting interests}

Authors declare that there is no conflict of interest. 


\section{References}

1. Tuan RS, Chen AF and Klatt BA. Cartilage regeneration. J Am Acad Orthop Surg. 2013; 21: 303-11.

2. Salzmann GM, Sah B, Sudkamp NP and Niemeyer P. Reoperative characteristics after microfracture of knee cartilage lesions in 454 patients. Knee Surg Sports Traumatol Arthrosc. 2013; 21: 365-71.

3. Goldring MB, Tsuchimochi K and ljiri K. The control of chondrogenesis. J Cell Biochem. 2006; 97: 33-44.

4. Spater D, Hill TP, Gruber M and Hartmann C. Role of canonical Wnt-signalling in joint formation. Eur Cell Mater. 2006; 12: 71-80.

5. Yasuhara R, Ohta Y, Yuasa T, et al. Roles of beta-catenin signaling in phenotypic expression and proliferation of articular cartilage superficial zone cells. Lab Invest. 2011; 91: 1739-52.

6. Kirton JP, Crofts NJ, George SJ, Brennan K and Canfield AE. Wnt/beta-catenin signaling stimulates chondrogenic and inhibits adipogenic differentiation of pericytes: potential relevance to vascular disease? Circ Res. 2007; 101: 581-9.

7. Nemoto T, Kanai T, Yanagita T, et al. Regulation of Akt mRNA and protein levels by glycogen synthase kinase-3beta in adrenal chromaffin cells: effects of $\mathrm{LiCl}$ and SB216763. Eur J Pharmacol. 2008; 586: 82-9.

8. Stambolic V, Ruel $L$ and Woodgett JR. Lithium inhibits glycogen synthase kinase-3 activity and mimics wingless signalling in intact cells. Curr Biol. 1996; 6: 16648.

9. Eslaminejad MB, Karimi N and Shahhoseini M. Chondrogenic differentiation of human bone marrow-derived mesenchymal stem cells treated by GSK-3 inhibitors. Histochem Cell Biol. 2013; 140: 623-33.

10. Baghaban Eslaminejad M, Karimi N and Shahhoseini M. Enhancement of Glycosaminoglycan-Rich Matrix Production in Human Marrow-Derived Mesenchymal 
Stem Cell Chondrogenic Culture by Lithium Chloride and SB216763 Treatment. Cell J. 2011; 13: 117-26.

11. Yano F, Kugimiya F, Ohba S, et al. The canonical Wnt signaling pathway promotes chondrocyte differentiation in a Sox9-dependent manner. Biochem Biophys Res Commun. 2005; 333: 1300-8.

12. Thompson CL, Yasmin H, Varone A, Wiles A, Poole CA and Knight MM. Lithium chloride prevents interleukin-1beta induced cartilage degradation and loss of mechanical properties. J Orthop Res. 2015.

13. Minashima $\mathrm{T}$, Zhang $\mathrm{Y}$, Lee $\mathrm{Y}$ and Kirsch $\mathrm{T}$. Lithium protects against cartilage degradation in osteoarthritis. Arthritis Rheumatol. 2014; 66: 1228-36.

14. Hui W, Litherland GJ, Jefferson M, et al. Lithium protects cartilage from cytokine-mediated degradation by reducing collagen-degrading MMP production via inhibition of the P38 mitogen-activated protein kinase pathway. Rheumatology (Oxford). 2010; 49: 2043-53.

15. Maçon ALB, Jacquemin M, Page SJ, et al. Lithium-silicate sol-gel bioactive glass and the effect of lithium precursor on structure-property relationships. $J$ sol-gel sci techn. 2016; DOI: 10.1007/s10971-016-4097-x .

16. Saravanapavan $P$ and Hench LL. Low-temperature synthesis, structure, and bioactivity of gel-derived glasses in the binary $\mathrm{CaO}-\mathrm{SiO} 2$ system. J Biomed Mater Res. 2001; 54: 608-18.

17. Owens GJ, Singh RK, Foroutan F, et al. Sol-gel based materials for biomedical applications. Prog Mater Sci. 2016; 77: 1-79.

18. Khorami M, Hesaraki S, Behnamghader A, Nazarian $\mathrm{H}$ and Shahrabi S. In vitro bioactivity and biocompatibility of lithium substituted $45 \mathrm{~S} 5$ bioglass. Mater Sci Eng $C$. 2011; 31: 1584-92.

19. Miguez-Pacheco V, Büttner T, Maçon ALB, et al. Development and characterization of lithium-releasing silicate bioactive glasses and their scaffolds for bone repair. Journal of Non-Crystalline Solids. 2016; 432, Part A: 65-72. 
20. Han P, Wu C, Chang J and Xiao Y. The cementogenic differentiation of periodontal ligament cells via the activation of Wnt/beta-catenin signalling pathway by $\mathrm{Li}+$ ions released from bioactive scaffolds. Biomaterials. 2012; 33: 6370-9.

21. Wu Y, Zhu S, Wu C, et al. A Bi-Lineage Conducive Scaffold for Osteochondral Defect Regeneration. Adv Funct Mater. 2014; 24: 4473-83.

22. Wu C and Chang J. Multifunctional mesoporous bioactive glasses for effective delivery of therapeutic ions and drug/growth factors. J Control Release. 2014; 193 : 282-95.

23. Catauro M, Papale F, Sapio $L$ and Naviglio S. Biological influence of $\mathrm{Ca} / \mathrm{P}$ ratio on calcium phosphate coatings by sol-gel processing. Materials science \& engineering C, Materials for biological applications. 2016; 65: 188-93.

24. Varanasi VG, Leong KK, Dominia LM, Jue SM, Loomer PM and Marshall GW. $\mathrm{Si}$ and $\mathrm{Ca}$ individually and combinatorially target enhanced MC3T3-E1 subclone 4 early osteogenic marker expression. J Oral Implantol. 2012; 38: 325-36.

25. Saffarian Tousi N, Velten MF, Bishop TJ, et al. Combinatorial effect of Si4+, $\mathrm{Ca} 2+$, and $\mathrm{Mg} 2+$ released from bioactive glasses on osteoblast osteocalcin expression and biomineralization. Materials science \& engineering C, Materials for biological applications. 2013; 33: 2757-65.

26. Zhai W, $\mathrm{Lu} \mathrm{H}, \mathrm{Wu} \mathrm{C}$, et al. Stimulatory effects of the ionic products from Ca$\mathrm{Mg}-\mathrm{Si}$ bioceramics on both osteogenesis and angiogenesis in vitro. Acta Biomaterialia. 2013; 9: 8004-14.

27. Alves EG, Serakides R, Rosado IR, et al. Effect of the ionic product of bioglass 60s on osteoblastic activity in canines. BMC Vet Res. 2015; 11: 247.

28. Bonen DK and Schmid TM. Elevated extracellular calcium concentrations induce type X collagen synthesis in chondrocyte cultures. J Cell Biol. 1991; 115: 11718.

29. Tare RS, Mitchell PD, Kanczler J and Oreffo RO. Isolation, differentiation, and characterisation of skeletal stem cells from human bone marrow in vitro and in vivo. Methods in molecular biology. 2012; 816: 83-99. 
30. Li S, Sengers BG, Oreffo RO and Tare RS. Chondrogenic potential of human articular chondrocytes and skeletal stem cells: a comparative study. J Biomater Appl. 2015; 29: 824-36.

31. Mackay AM, Beck SC, Murphy JM, Barry FP, Chichester CO and Pittenger MF. Chondrogenic differentiation of cultured human mesenchymal stem cells from marrow. Tissue engineering. 1998; 4: 415-28.

32. Malpeli M, Randazzo N, Cancedda R and Dozin B. Serum-free growth medium sustains commitment of human articular chondrocyte through maintenance of Sox9 expression. Tissue engineering. 2004; 10: 145-55.

33. Lison L. Alcian blue $8 \mathrm{G}$ with chlorantine fast red 5 B.A technic for selective staining of mycopolysaccharides. Stain Technol. 1954; 29: 131-8.

34. Negishi $\mathrm{Y}$, Kudo A, Obinata A, et al. Multipotency of a bone marrow stromal cell line, TBR31-2, established from ts-SV40 T antigen gene transgenic mice. Biochem Biophys Res Commun. 2000; 268: 450-5.

35. Stricker S, Fundele R, Vortkamp A and Mundlos S. Role of Runx genes in chondrocyte differentiation. Dev Biol. 2002; 245: 95-108.

36. Farndale RW, Buttle DJ and Barrett AJ. Improved quantitation and discrimination of sulphated glycosaminoglycans by use of dimethylmethylene blue. Biochimica et biophysica acta. 1986; 883: 173-7.

37. Knight MM, Lee DA and Bader DL. The influence of elaborated pericellular matrix on the deformation of isolated articular chondrocytes cultured in agarose. Biochimica et biophysica acta. 1998; 1405: 67-77.

38. Li S, Glynne-Jones P, Andriotis OG, et al. Application of an acoustofluidic perfusion bioreactor for cartilage tissue engineering. Lab Chip. 2014; 14: 4475-85. 39. Logan CY and Nusse R. The Wnt signaling pathway in development and disease. Annu Rev Cell Dev Biol. 2004; 20: 781-810.

40. Clevers $\mathrm{H}$ and Nusse R. Wnt/beta-catenin signaling and disease. Cell. 2012; 149: 1192-205. 
41. Kikuchi A, Yamamoto $H$ and Sato A. Selective activation mechanisms of Wnt signaling pathways. Trends Cell Biol. 2009; 19: 119-29.

42. Nalesso G, Sherwood J, Bertrand J, et al. WNT-3A modulates articular chondrocyte phenotype by activating both canonical and noncanonical pathways. $J$ Cell Biol. 2011; 193: 551-64.

43. Huang $\mathrm{H}$ and $\mathrm{He} X$. Wnt/beta-catenin signaling: new (and old) players and new insights. Curr Opin Cell Biol. 2008; 20: 119-25.

44. Hedgepeth CM, Conrad LJ, Zhang J, Huang HC, Lee VM and Klein PS.

Activation of the Wnt signaling pathway: a molecular mechanism for lithium action. Dev Biol. 1997; 185: 82-91.

45. Sassi N, Laadhar L, Allouche M, et al. WNT signaling and chondrocytes: from cell fate determination to osteoarthritis physiopathology. J Recept Signal Transduct Res. 2014; 34: 73-80.

46. Kapadia RM, Guntur AR, Reinhold MI and Naski MC. Glycogen synthase kinase 3 controls endochondral bone development: contribution of fibroblast growth factor 18. Dev Biol. 2005; 285: 496-507.

47. Kawata K, Kubota S, Eguchi T, et al. Role of the low-density lipoprotein receptor-related protein-1 in regulation of chondrocyte differentiation. J Cell Physiol. 2010; 222: 138-48.

48. Schulze-Tanzil G. Activation and dedifferentiation of chondrocytes: implications in cartilage injury and repair. Ann Anat. 2009; 191: 325-38.

49. Carlisle EM. Silicon as an essential trace element in animal nutrition. Ciba Found Symp. 1986; 121: 123-39.

50. Carlisle EM. Silicon: a requirement in bone formation independent of vitamin D1. Calcif Tissue Int. 1981; 33: 27-34.

51. Carlisle EM. In vivo requirement for silicon in articular cartilage and connective tissue formation in the chick. J Nutr. 1976; 106: 478-84. 
52. Nielsen FH. Update on the possible nutritional importance of silicon. Journal of trace elements in medicine and biology : organ of the Society for Minerals and Trace Elements. 2014; 28: 379-82.

53. Xynos ID, Edgar AJ, Buttery LD, Hench LL and Polak JM. Gene-expression profiling of human osteoblasts following treatment with the ionic products of Bioglass $45 S 5$ dissolution. J Biomed Mater Res. 2001; 55: 151-7.

54. Kim EJ, Bu SY, Sung MK and Choi MK. Effects of silicon on osteoblast activity and bone mineralization of MC3T3-E1 cells. Biological trace element research. 2013; 152: 105-12.

55. Gupta G, Kirakodu S and El-Ghannam A. Dissolution kinetics of a Si-rich nanocomposite and its effect on osteoblast gene expression. J Biomed Mater Res $A$. 2007; 80: 486-96.

56. Mueller MB and Tuan RS. Functional characterization of hypertrophy in chondrogenesis of human mesenchymal stem cells. Arthritis Rheum. 2008; 58: 137788.

57. Mackay AM, Beck SC, Murphy JM, Barry FP, Chichester CO and Pittenger MF. Chondrogenic differentiation of cultured human mesenchymal stem cells from marrow. Tissue Eng. 1998; 4: 415-28.

58. van der Kraan PM, Blaney Davidson EN, Blom A and van den Berg WB. TGFbeta signaling in chondrocyte terminal differentiation and osteoarthritis: modulation and integration of signaling pathways through receptor-Smads. Osteoarthritis Cartilage. 2009; 17: 1539-45.

59. Shukunami C, Ishizeki K, Atsumi T, Ohta Y, Suzuki F and Hiraki Y. Cellular hypertrophy and calcification of embryonal carcinoma-derived chondrogenic cell line ATDC5 in vitro. J Bone Miner Res. 1997; 12: 1174-88.

60. Shukunami C, Shigeno C, Atsumi T, Ishizeki K, Suzuki F and Hiraki Y. Chondrogenic differentiation of clonal mouse embryonic cell line ATDC5 in vitro: differentiation-dependent gene expression of parathyroid hormone (PTH)/PTH-related peptide receptor. J Cell Biol. 1996; 133: 457-68. 


\section{Figures and captions}



Figure 1. Alcian blue and Sirius red (A/S) staining of day 7, 14 and 21 ATDC5 cell pellet cultures. ATDC5 cells were cultured as $3-D$ pellets $\left(2.5 \times 10^{5}\right.$ cells per pellet) in dissolution products of $\mathrm{SiO}_{2}-\mathrm{Li}_{2} \mathrm{O}$ and $\mathrm{S} 100$ sol-gel derived glass with and without the presence of chondrogenic supplements. $\mathrm{SiO}_{2}-\mathrm{Li}_{2} \mathrm{O}$ glass dissolution appeared to improve cartilaginous matrix formation without the presence of chondrogenic supplements. Chondrogenic differentiation and cartilaginous matrix formation was observed in pellets collected as early as 7 day. Scale bar $=200 \mu \mathrm{m} . \mathrm{n}=3$, representative images were shown. 


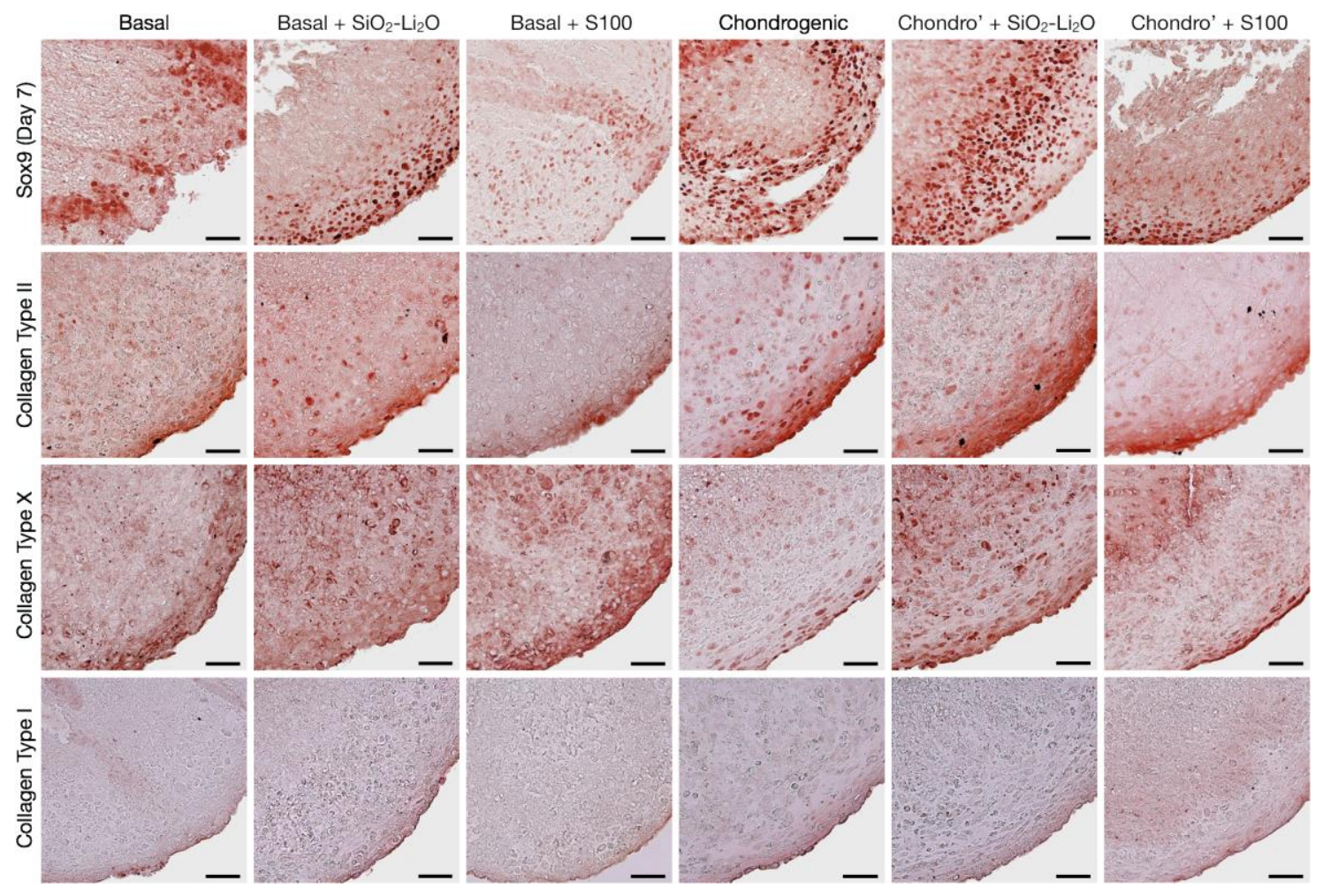

Figure 2. Immunohistochemical analysis of day 7 and 21 ATDC5 cell pellet cultures. $\mathrm{SiO}_{2}-\mathrm{Li}_{2} \mathrm{O}$ glass dissolution improved the expression of Sox9 (day 7) and Collagen Type II (day 21). The expression of chondrocyte hypertrophy marker, Collagen Type $X$ was also elevated by both types of sol-gel derived glasses. The addition of chondrogenic supplements appeared to supress chondrocyte hypertrophy. The expression of Collagen Type I (day 21) was not affected by any of the test conditions. Scale bar $=200 \mu \mathrm{m} . \mathrm{n}=3$, representative images were shown. 

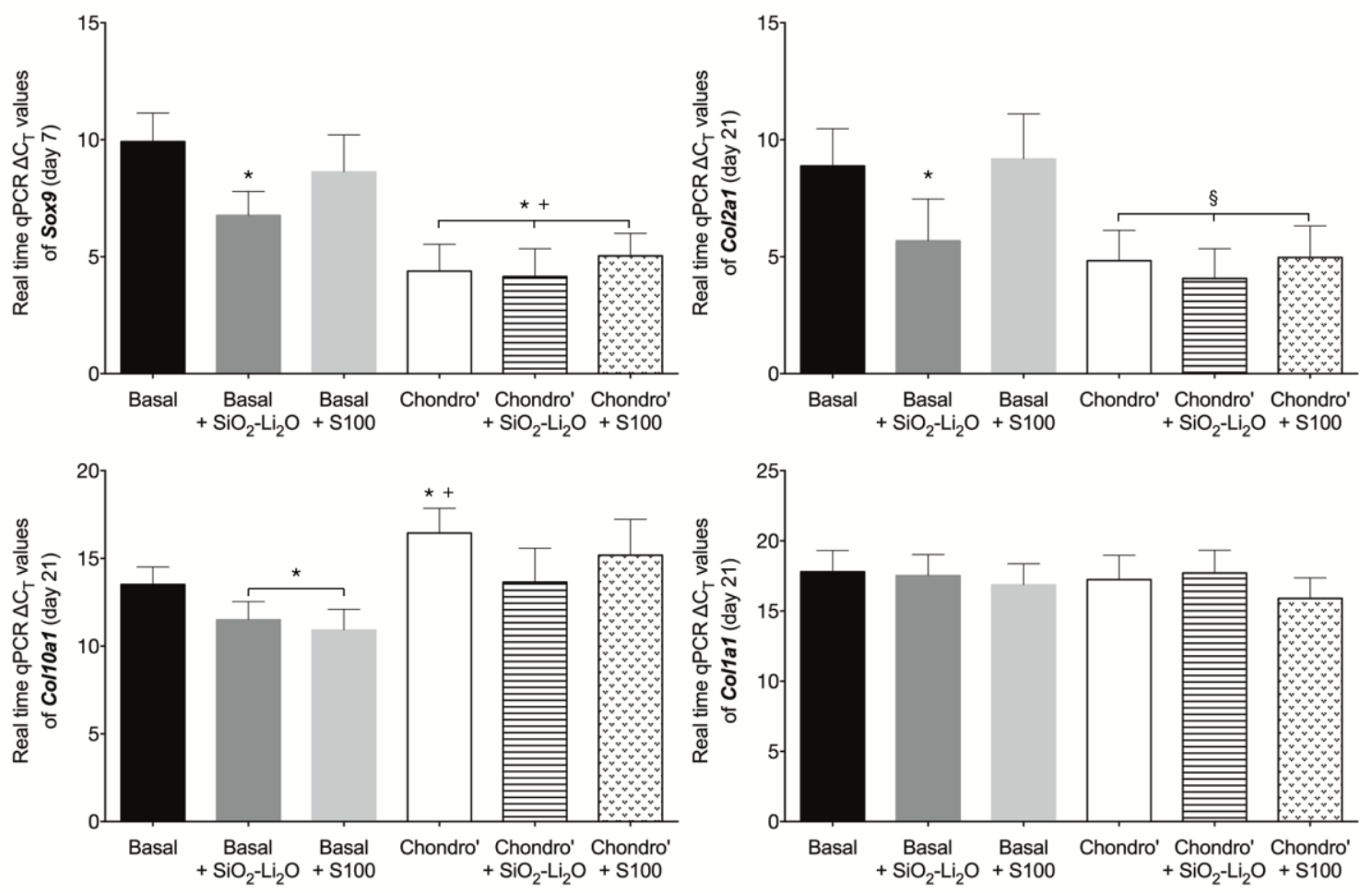

Figure 3. Real-time qPCR analysis of expression

of Sox9, Col2a1, Col10a1 and Col1a1 transcripts in day-7 and day-21 pellets generated using $2.5 \times 10^{5}$ ATDC5 cells in various culture conditions. Relative expression levels ( $\Delta \mathrm{C}_{\mathrm{T}}$ values) of the genes of interests were normalised to the expression of the housekeeping gene, $\beta$-Actin, i.e. the value of $\Delta \mathrm{C}_{\mathrm{T}}$ is reversely proportional to the expression of the gene of interest. Bar graphs were plotted and statistical analysis was performed at the level of $\Delta C_{T}(n=3) .{ }^{*} p<0.05$ in comparison to basal, $+p<0.05$ in comparison to basal and basal $+\mathrm{SiO}_{2}-\mathrm{Li}_{2} \mathrm{O}$ and, $\S \mathrm{p}<0.05$ in comparison to basal but $\mathrm{p}>0.05$ in comparison to $\mathrm{SiO}_{2}-\mathrm{Li}_{2} \mathrm{O}$ 


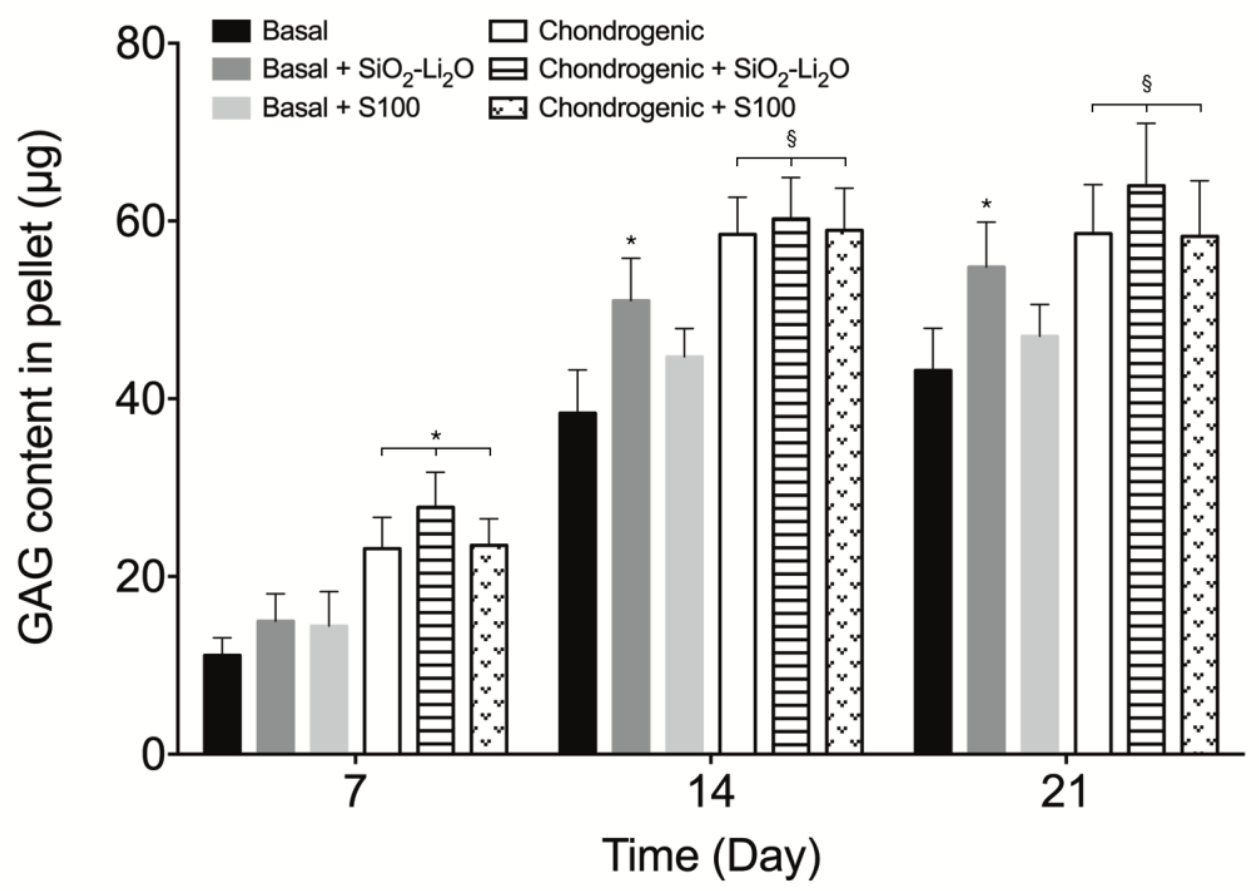

Figure 4. Quantification of sulphated GAG content in day-21 ATDC5 pellets using DMMB assay. Bar graph was plotted as mean \pm S.D. $(n=3) \cdot \mathrm{SiO}_{2}-\mathrm{Li}_{2} \mathrm{O}$ glass dissolution products alone improved the synthesis of GAG in pellets to a level comparable to those cultured in chondrogenic supplements by day 14 . ${ }^{*} p<0.05$ in comparison to basal and, $\$ p<0.05$ in comparison to basal but $p>0.05$ in comparison to basal $+\mathrm{SiO}_{2}-\mathrm{Li}_{2} \mathrm{O}$. 